MINERALOGIA, 47, No 1-4: 7-10 (2016)

\title{
DE
}

DE GRUYTER OPEN

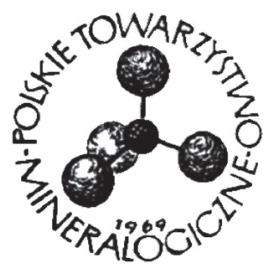

Printed in 2017

\section{Professor Mieczysław Żyła (1930 - 2014)}

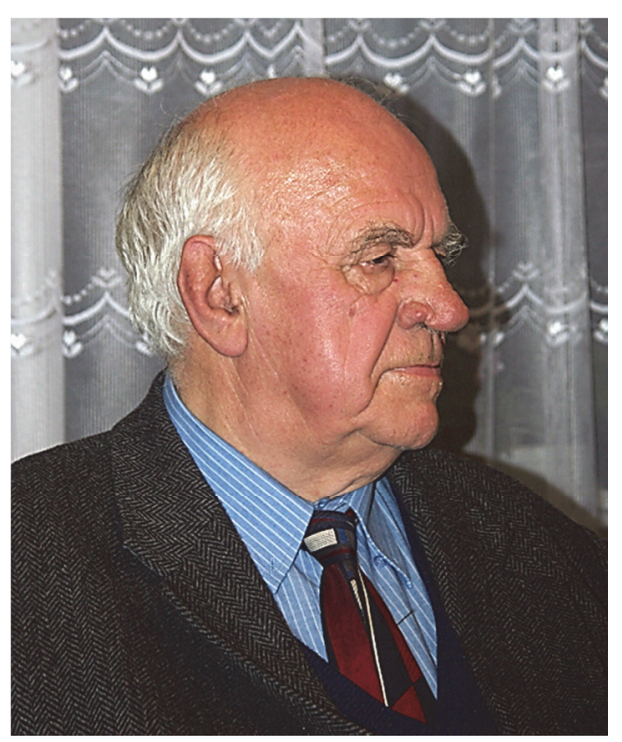

With the deepest grief, Mr Mieczysław Żyła, Professor of the University of Science and Technology in Krakow, who died on 29 January 2014, is remembered by the whole faculty.

Prof. D. Sc. Mieczysław Żyła was born on May 10, 1930 in Krakow. The period of his study and career was related to this city. It was here that he achieved his mature graduation in the Secondary Comprehensive School named after A. Witkowski in 1950. In the same year, he started his chemical studies at the Mathematical-Physical-Chemical Department of the Jagiellonian University, he continued second-cycle studies at the Faculty of Physical Chemistry and Electrochemistry under the supervision of Prof. B. Kamieński. He graduated from the University in 1955. In November 1954, still being a student in the 5th year, he accepted his first placement as an academic tutor at the Agricultural Department of the Higher School of Agriculture. In 1958, he commenced work at the University of Science and Technology as an academic tutor at the Faculty of Mining Chemistry headed by Prof. L. Czerski. At the University, he progressed through all the ranks and stages of scientific and didactic development. In 1963, he obtained a Doctor of Technical Science degree after defending a thesis entitled "Research on the relation between the sorptive properties of hard coals and their chemical nature". His habilitation to an assistant professor in 1973 was based on published monograph on the sorptive properties of thermally modified bentonites and montmorillonite from the Chmielnik mine. In 1990, he gained the rank of associate professor, and, in 1993, of full professor. 
In his scientific activity, Professor Mieczysław Żyła consistently studied phenomena of adsorption on coals and mineral substances ("black" and "white" sorbents), establishing himself as a well-known and valued specialist in this field.

At the beginning of his career, while under supervision of Professor Mieczysław Lason, he conducted research on the physics and chemistry of hard-coal surfaces. The excellent outcome of this work was his doctoral dissertation.

Another period of Professor Żyła's scientific activity involved aluminosilicate sorbents, mostly zeolites and clay minerals. In his work, he investigated the sorptive properties of Polish industrially-produced synthetic particle sieves, as well as natural zeolites- stilbite and heulandite. This research was of a nature-cognitive character. Materials and clay minerals, their sorption properties in relation to vapors of polar and apolar substances as well as the changes in these properties after modification of the examined samples using ion exchange or thermal activation, were the subject of a habilitation monograph. This work presented a study of the sorption of water vapor, methanol, argon and hexane on samples of bentonites and the extracted montmorillonite, as well as on the porosity of the initial samples and samples after thermal modification. Professor Żyła's involvement, during this time, in the construction of a specialized apparatus for sorptive experimentation merits emphasis. Long before the construction of the sorption machine, he produced microburettes for liquids that allowed one to very precisely determine adsorption and desorption isotherms for many liquid adsorbates. The thesis qualifying him for an assistantprofessorship opened a 20-year-long period of Professor Żyła's scientific career when the predominant subject matters concerned the sorptive properties of clay minerals, and materials obtained as a result of their intercalation with hydroxy-metal oligocations, hydrophobisation with organic compounds or incorporation of coal deposits. The initial material was mainly montmorillonite, but some of his studies also concerned kaolinite and diatomite.

That period was also one of successful co-operation with mineralogists from the Department of Geology (present name: Department of Geology, Geophysics and Environmental Protection) who were interested in the same subject matter. There, Professor Żyła was always prominent in the design and execution of sorption research, as well as in the interpretation of the results. The research conducted by Professor Żyła were not only of a cognitive character, but partly focused on possibilities for the utilization of the used sorbents, after appropriate modification in a way that they could be used in other technologies, or for environmental protection.

In subsequent years, Professor Żyła returned to his initial subject of study, namely, hard coals. He investigated the influence of the chemical character of coal surfaces on their sorptive properties with reference to a sorbates vapors with a different degree of polarity. From that time on, his close scientific co-operation with the Central Mining Institute in Katowice developed.

Professor Żyła's didactic activity was mainly connected with his own Department where, for many years, he delivered lectures on general chemistry and on specialized subjects such as the physics and chemistry of coal surface and the technology of mineral sorbents. Apart from lectures on his Faculty and in University (he delivered lectures in chemistry at the Mining Department and Department of Drilling, Oil and Gas) he had lectures outside Krakow, in several divisions of the AGH. He participated in the 
preparation of sub-literature with exercises in general chemistry and physical chemistry as well as hard coal physics and chemistry for students and academic teachers. He was a promoter of several tens of diploma dissertations and several doctoral theses. His first doctoral graduate is now a scientist of worldwide esteem holding a professor's chair at an American University.

Professor's Żyła's didactic activity, the substantial content of his classes and lectures and his way of sharing knowledge with his students, was always greatly appreciated and respected by them. Several Rector's didactic awards conferred at the request of the student government demonstrated their dedication to him.

The published scientific output of Professor Mieczysław Żyła includes nearly 90 articles in domestic and foreign journals and over 70 conference papers. He is the author of chapters in two monographs on the scope of mineral aluminosilicate sorbents, and a further two chapters concerning structure and properties of hard coals.

It was through Professors Żyła's initiative and with his editorship that the monograph "Hard-coal methane system in an aspect of desorption and recovery of methane from mine gases", with his extensive chapter on the structural and sorptive properties of hard coals was published at the Department of Fuels and Energy. The publishing of this monograph reflected his enormous contribution as a scientist and supervisor to research conducted on hard coal.

Another important area of Professor Żyła's activity was his organizational work. He was a founder of the Mineral Sorbents Plant at the Faculty of Mining Chemistry of the Mining Department at the AGH and a co-organizer of the Institute of Coal Energy and Chemistry and Sorbent Physics and Chemistry (working on a faculty rights) at the AGH University where, from 1984-1990, he was the Head Manager and, from 1990-1993, Dean of an officially established Department of Coal Energochemistry and Sorbent Physics and Chemistry. In 1995, the department became Department of Fuels and Energy and, in 2008, merged with the Interdepartmental School of Power Engineering to become the present Department of Energy and Fuels of the AGH.

Professor Żyła's organizational activities did not only affect the scope of the Department as he was also a member of the AGH Senate, taking part in the work of the Senate's Committee for the Development of the Scientific Faculty of the University. He was also connected with Polish Academy of Sciences, being a member of the Scientific Board of the Strata Mechanics Research Institute, PAN, and of the Committee for Surface Phenomena, PAN. He was also a co-organizer of several domestic conferences, namely, the seminars "Coal surface '90", "Coal surface '93", "Hard coal - properties, accumulation, release and recovery of mine gases" (1994), and "Coal - coal sorbents" (1998). The research on hard coal presented at these conferences proved to be of great interest to coresearchers in other scientific- and industrial centers.

Having retired in 2000, Professor Żyła still remained in lively contact with the University; his nearby residence enabled him to visit his Department almost every day. Not only was he interested in the lives of his younger associates and graduates, their scientific careers and the everyday matters of the Institute, the Department, and the University, but he also actively participated in scientific work. During this period, he issued several reviews, was a co-author of one book and of chapters in three monographs, 15 articles in scientific journals, and materials presented at 11 conferences. 
Professor Żyła received numerous awards and honors for his achievements. For his scientific and didactic activities, he was repeatedly honored by the Rector. He received the prestigious Władysław Takliński Award (Grade 1) and two awards conferred by the Minister of Science, Higher Education and Technology. He was also honored with the Knight's Cross of the Order of Polonia Restituta, the Gold Cross of Merit, the Gold Badge of the Polish Teachers' Union, and the Silver Badge of Merit for Ziemia Krakowska (Land of Krakow).

Professor Mieczysław Żyła was a man of great heart with a passion for science. His attitude towards both students and associates was kind-hearted and encouraging.

The Professor will stay for ever in our memory, which, on behalf of graduates and colleagues, is assured by

Andrzej Krzyżanowski

Faculty of Energy and Fuels AGH UST 